\title{
Bone density in sheep: genetic variation and quantitative trait loci localisation
}

\author{
A.W. Campbell, ${ }^{*}$ W.E. Bain, A.F. McRae, T.E. Broad, ${ }^{1}$ P.D. Johnstone, K.G. Dodds, \\ B.A. Veenvliet, G.J. Greer, B.C. Glass, A.E. Beattie, N.B. Jopson, ${ }^{2}$ and J.C. McEwan \\ AgResearch, Invermay Agricultural Centre, Private Bag 50034, Mosgiel, New Zealand
}

Received 4 February 2003; revised 15 June 2003; accepted 18 June 2003

\begin{abstract}
Bone density (BD) is an important factor in osteoporotic fracture risk in humans. However, BD is a complex trait confounded by environmental influences and polygenic inheritance. Sheep provide a potentially useful model for studying differences in BD, as they provide a means of circumventing complex environmental factors and are a similar weight to humans. The aims of this study were to establish whether there is genetic variation in BD in sheep and then to localise quantitative trait loci (QTLs) associated with this variation. We also aimed to evaluate the relationship between fat and muscle body components and BD in sheep. Results showed that there was significant $(P<0.01)$ genetic variation among Coopworth sheep sires for BD. This genetic difference was correlated $(P<0.01)$ with body weight and muscle mass. A number of QTLs exceeding the suggestive threshold were identified (nine in total). Of these, two (chromosomes $1, P<0.05$; chromosome $24, P<0.01$ ) were significant using genome-wide permutation significance thresholds (2000 iterations). The position of the QTL on chromosome 24 coincided with a number of other body composition QTLs, indicating possible pleiotropic effects or the presence of multiple genes affecting body composition at that site. This study shows that sheep are potentially a useful model for studying the genetics of BD.
\end{abstract}

(C) 2003 Elsevier Inc. All rights reserved.

Keywords: Bone density; Genetics; Sheep

\section{Introduction}

Low bone density (BD) has been shown to be an important factor in osteoporotic fracture risk in humans [1-3]. Osteoporosis is a complex disease influenced by environmental factors such as nutrition, exercise, exposure to sunlight, and pharmacologic agents, as well as endogenous variables such as reproductive status, aging, disease states, and serum hormone and mineral levels [4]. However, there is a strong genetic component to $\mathrm{BD}$ and an individual's genetic makeup is thought to contribute $60-70 \%$ of the

\footnotetext{
* Corresponding author. Fax: +64-3-489-3739.

E-mail address: anna.campbell@agresearch.co.nz (A.W. Campbell).

${ }^{1}$ Current address: Australian Equine Genetic Research Centre, University of Queensland, St. Lucia, Brisbane, Queensland 4072, Australia.

${ }^{2}$ Current address: Abacus Biotech Limited, P.O. Box 5585, Dunedin, New Zealand.
}

normal variability in $\mathrm{BD}$, in combination with these other factors [4]. Knowledge of the influence of genetics on BD in humans has been obtained from twin studies $[5,6]$, multigenerational family studies [7,8], and sib pair analyses [9].

$\mathrm{BD}$ is a polygenic trait dependent on the action of a number of genes. A number of functional candidate genes have been associated with low BD. However, results from functional candidate gene studies have not been consistently replicated [10]. For example, the gene for the vitamin D receptor has been found to be associated with $\mathrm{BD}$ in some studies [11,12] but not others [13,14].

Quantitative trait loci (QTL) analysis is an alternate approach, which enables identification of a chromosome region associated with variation in a trait of interest. QTL studies of BD have been carried out in humans $[7,10,15,16]$, mice [4], and pedigreed baboons [17]. An advantage of this approach is that it enables the identification of positional candidate genes and provides an area for focussed fine 
mapping experiments. For example, a causative mutation in the lipoprotein (LDL) receptor-related protein related to high bone mass has recently been identified [18] from a QTL on chromosome 11q12-13 detected in humans [19].

One of the factors hindering advances in osteoporosis research is the lack of an adequate animal model. Primates, dogs, cats, rabbits, mice, and pigs have been used for studying osteoporosis [20], but the results are often controversial because of (a) the wide variation in bone metabolism and remodeling between one species and another [21], (b) the use of ovariectomy, steroids, and/or vitamin D deficiency to induce osteoporosis [21-23], (c) size difficulties for use in testing bone forming agents, and (d) ethical considerations.

There are advantages in using sheep as an animal model. Sheep have a similar bone remodeling process to that of humans [22], they are of a comparable size to humans, and they are docile and easily maintained. However, they are not suitable for studies involving oral absorption of drugs, because of their different gastrointestinal system, and the fact that they are quadripedal must be taken into account in interpretation of results. Sheep are potentially an excellent animal model for studying bone disorders associated with $\mathrm{BD}$ as well as the mechanisms responsible for bone fracturing and healing. A clearer understanding of the genetics of BD in sheep would provide a means of developing an osteoporotic animal model through breeding.

The aim of the present study was to establish whether there is variation in BD in sheep and, if so, whether some of this variation is due to genetic factors. We then aimed to localise QTLs associated with the genetic variation for BD in sheep. Finally, given that body weight is correlated with BD in humans, we wanted to establish whether body weight and fat and muscle components were correlated with sheep BD.

\section{Materials and methods}

\section{Animals}

Lines of Coopworth sheep have been selected for and against live weight adjusted ultrasonic back fat depth over the 12 th rib over 14 years and 10 generations, since 1981 [24]. Extreme animals from each of the lean and fat lines (three sires and nine ewes per line) were selected on the basis of animal model BLUP (best linear unbiased prediction) breeding values and were mated to produce $F_{1}$ cross animals [25]. Five $F_{1}$ sires were then reciprocally backcrossed with the parental lines to produce large $1 / 2 \mathrm{sib}$ families (family sizes: sire 603-150 progeny; sire 608-168 progeny; sire 610-37 progeny; sire 616-171 progeny; sire 620-105 progeny) over 2 years (1995 and 1996) for use in a QTL detection experiment for body compositional traits. The lambs from each year were managed together until weaning at approximately 10 weeks of age when they were separated into two mobs by sex. At 7 months of age the lambs were moved indoors and given ad libitum access to a high-quality pelleted ration through the winter to ensure high levels of live weight gain over this period.

\section{Phenotypic measurements}

Traits associated with BD were measured in both 1995 and 1996. These included birth weight, weaning weight at 10 weeks of age, and autumn weight at an average of 6 months of age. At 9 months of age lambs were weighed and $\mathrm{X}$-ray computed tomography (CT) scanned to measure body composition.

Bone density was estimated from X-ray computed tomography (CT; Siemens Somatom AR.C, Erlangen, Germany) images in a total of 629 lambs at 9 months of age from both year classes. Lambs were CT scanned using a protocol similar to that described for deer [26]. Briefly, lambs were fasted overnight prior to CT scanning. For scanning, lambs were sedated with an intramuscular injection of $0.1 \mathrm{mg} / \mathrm{kg}$ acepromazine maleate (ACP, [C-Vet Veterinary Products]). The lambs were then physically restrained in a supine position with forelimbs flexed and hind limbs fully extended.

CT images comprised a series of cross-sectional images recorded at 50-mm intervals throughout the body using a stereological technique [27]. The images were collected from a point behind the rump (i.e., distal to the proximal hind leg muscles) and forward through to the first cervical vertebra. An average of 18 images was recorded for each animal. Images were $400 \mathrm{~mm}$ in diameter and $5 \mathrm{~mm}$ in width. The X-ray tube operated at $130 \mathrm{kV}$ and $70 \mathrm{~mA}$ and the "Body4" reconstruction algorithm was used.

The image density units (Hounsfield units; HU) are related to the physical density of the various tissues [28]. CT images were segmented into fat, lean, and bone based on their HU value ranges. Pixels with densities between -200 and $-18 \mathrm{HU}$, between -17 and $120 \mathrm{HU}$, and greater than $120 \mathrm{HU}$ were considered fat, lean, and bone, respectively. For the purposes of this experiment bone (i.e., tissues with an equivalent $\mathrm{HU}$ range to bone) was classified into one of four groups, namely the long bones, flat bones of the pelvic cradle and scapula, spine, and ribs. Fat comprised the total fat in the body and included the combined subcutaneous, intermuscular, omental, mesenteric, kidney, and channel depots. Carcass lean comprised all tissues that could be identified as muscle mass. The area and average HU density value for fat, lean, and the four bone classes were recorded in every CT image for each individual animal. The average number of images and standard deviations taken for each group was long bones $7.9 \pm 0.8$; flat bones $6.7 \pm 1.0$; spinal bones $16.1 \pm 1.0$; rib bones $5.6 \pm 0.8$. It was possible to calculate the density and weight of each tissue from the CT image. The weighted average density was calculated as the sum of the mean of HU value multiplied by the crosssectional area of tissue in each image, divided by the sum of the cross-sectional area of tissue in each image. The use of 
HU density as an absolute value for BD may be influenced by machine drift and beam hardening artifacts [29]. However, the repeatability of $\mathrm{HU}$ value measurement in the lumbar spine of adult sheep using this technique in a previous study was high (coefficient of variation of $1.85 \%$; unpublished data) and the residual standard deviation for prediction of BD from $\mathrm{HU}$, for scapula, femur, and rib, was $0.04 \mathrm{~g} / \mathrm{cm}^{3}$. The prediction of BD $\left(\mathrm{g} / \mathrm{cm}^{3}\right)$ of each tissue was calculated as a function of $\mathrm{HU}$ where

$$
\text { density }=\mathrm{HU} \times 0.00106+1.0062 .
$$

Tissue weights were calculated from the volume and average density, where volume was estimated by numerical integration of the tissue area in each image multiplied by the distance between images [27].

\section{Genetic analyses}

Blood samples were collected from all sires and their progeny. The white blood cells in these samples were harvested after ammonium chloride lysis of erythrocytes [30]. Two hundred microsatellite markers, previously mapped in sheep [31], were screened over the $F_{1}$ sires and 138 equally spaced markers that were polymorphic for an individual sire were then used to genotype its progeny and the parents of the $F_{1}$ sire.

\section{Statistical analyses}

The number of natural classifications for birth and rearing rank was collapsed to 4 after preliminary analysis showed that there were no significant differences between combined groups. The ages of the dams were collapsed to four groups, by classifying all dams greater than 4 years old into one group. The progeny were classified into two types. Type one were the progeny from an $F_{1}$ sire across a lean dam and type two were progeny from a $F_{1}$ sire across a fat dam.

QTL analysis was performed using the least squares approach [32] within $1 / 2 \mathrm{sib}$ families. The program used was a Genstat procedure [33]. The model fitted to the phenotypic data included terms which classified birth/rearing rank, gender, age of dam, and type of sire. The adequacy of the fitted model was extensively explored by applying the principle of parsimony [34] to more complex models involving interactions between the classifying terms. The adequacy of the assumptions underlying the statistical interpretation of the estimated parameters was assessed by the informal inspection of residual plots on fitted values, histograms of residuals, and $Q-Q$ plots. Both age- and weightadjusted analyses were performed. The age adjustments allowed for the differences in birth dates of the progeny and the weight adjustment allowed for the differences in live weight of the progeny nearest to the time a particular trait was measured. Initially, analyses were performed in 61 equally spaced steps through each of the chromosomes. The selection of QTLs for further investigation was based on the maximum of $-\log 10$ of the $P$ value of the F statistic of the sums of squares for individual sires after all other terms in the model had been fitted. The criterion used was that of Lander and Kruglyak [35] with 26 chromosomes and a genome length of $30.6 \mathrm{M}$. The permutation test of Churchill and Doerge [36] (2000 iterations) was also used to establish genome-wide significance levels for QTLs close to significance using the Lander and Kruglyak method [35].

Further statistical assessment was performed by calculating the allele substitution effects in phenotypic standard deviation units, the percentage of phenotypic variation contributed by the QTL, and 1 LOD support intervals for the QTL location [37]. Heritabilities were calculated with ASREML using univariate models including fixed effects for birth rearing rank, sex, age of dam, scan day, dam source, a covariate for empty body weight, and individual (animal) as a random effect. The analysis used pedigree relationships extending back to the establishment of the selection lines.

The power of the experiment to detect QTLs segregating within the five $1 / 2$ sib families at a genome-wide significance of 0.05 [35] (corresponding to a nominal significance of 0.0012 ) was evaluated [38,39]. The QTLs were assumed to be biallelic, with each allele at a frequency of 0.5. Polygenic heritability was assumed to be 0.5 .

\section{Results}

\section{Phenotypic traits}

The means, standard deviations, and minimums and maximums of the phenotypes measured for this study are listed in Table 1. Bone density measurements had normal distributions as shown in Figs. 1 to 4. Least squares means among sires, after adjustment for birth rearing rank, sex, age of dam, scan day, and sire type in long, flat, spinal, and rib bone groups, were highly significantly different for all bone groups $(P<0.01)$. Correlations of residuals (fixed for birth rearing rank, sex, age of dam, scan day, sire type) between BD measurements and body composition measurements were all highly significant $(P<0.01)$ (data not shown). When the residuals were fixed for empty body weight, correlations between $\mathrm{BD}$ and carcass lean (muscle) measurements were highly significant $(P<0.01)$ while fat measurements were not consistently correlated with BD (Table 2).

\section{Genetic analysis}

A total of 138 markers were genotyped over all progeny resulting in an average of 5 markers/chromosome (average distance between markers $19.7 \mathrm{cM}$ ) and a total map length 
Table 1

Means, standard deviations, and minimum and maximum values of phenotypes measured associated with bone density in coopworth sheep (raw data).

\begin{tabular}{|c|c|c|c|c|c|c|}
\hline \multirow[b]{2}{*}{ Phenotype } & & \multicolumn{5}{|l|}{ Sire } \\
\hline & & $603, n=150$ & $608, n=168$ & $610, n=37$ & $616, n=171$ & $620, n=105$ \\
\hline \multirow{4}{*}{$\begin{array}{l}\text { Long bones } \\
\left(\mathrm{g} \mathrm{cm}^{-3}\right)\end{array}$} & Mean & 1.490 & 1.477 & 1.461 & 1.462 & 1.495 \\
\hline & Std dev & 0.028 & 0.036 & 0.025 & 0.037 & 0.032 \\
\hline & Min & 1.427 & 1.377 & 1.426 & 1.355 & 1.429 \\
\hline & Max & 1.555 & 1.579 & 1.523 & 1.585 & 1.576 \\
\hline \multirow{4}{*}{$\begin{array}{l}\text { Flat bones }(\mathrm{g} \\
\left.\mathrm{cm}^{-3}\right)\end{array}$} & Mean & 1.410 & 1.365 & 1.376 & 1.369 & 1.403 \\
\hline & Std dev & 0.032 & 0.029 & 0.031 & 0.032 & 0.029 \\
\hline & Min & 1.310 & 1.289 & 1.319 & 1.287 & 1.342 \\
\hline & $\operatorname{Max}$ & 1.484 & 1.444 & 1.428 & 1.445 & 1.474 \\
\hline \multirow{4}{*}{$\begin{array}{l}\text { Spinal bones } \\
\qquad\left(\mathrm{g} \mathrm{cm}^{-3}\right)\end{array}$} & Mean & 1.393 & 1.345 & 1.363 & 1.340 & 1.387 \\
\hline & Std dev & 0.025 & 0.028 & 0.024 & 0.030 & 0.025 \\
\hline & Min & 1.334 & 1.256 & 1.312 & 1.237 & 1.319 \\
\hline & $\operatorname{Max}$ & 1.463 & 1.409 & 1.424 & 1.427 & 1.451 \\
\hline \multirow{4}{*}{$\begin{array}{l}\text { Rib bones ( } \mathrm{g} \\
\mathrm{cm}^{-3} \text { ) }\end{array}$} & Mean & 1.354 & 1.317 & 1.329 & 1.314 & 1.348 \\
\hline & Std dev & 0.023 & 0.024 & 0.024 & 0.024 & 0.025 \\
\hline & Min & 1.295 & 1.245 & 1.290 & 1.262 & 1.272 \\
\hline & $\operatorname{Max}$ & 1.410 & 1.377 & 1.387 & 1.385 & 1.412 \\
\hline \multirow{4}{*}{$\begin{array}{l}\text { Intermuscular } \\
\text { fat }(\mathrm{kg})\end{array}$} & Mean & 2.771 & 1.771 & 2.145 & 1.670 & 2.641 \\
\hline & Std dev & 0.601 & 0.474 & 0.472 & 0.541 & 0.605 \\
\hline & Min & 1.456 & 0.766 & 1.408 & 0.592 & 1.411 \\
\hline & $\operatorname{Max}$ & 4.375 & 3.121 & 3.042 & 3.412 & 4.125 \\
\hline \multirow{4}{*}{$\begin{array}{l}\text { Internal fat } \\
\quad(\mathrm{kg})\end{array}$} & Mean & 3.182 & 2.159 & 2.455 & 2.058 & 3.318 \\
\hline & Std dev & 0.734 & 0.636 & 0.557 & 0.605 & 0.842 \\
\hline & Min & 1.748 & 0.835 & 1.658 & 0.954 & 1.538 \\
\hline & $\operatorname{Max}$ & 6.238 & 3.783 & 3.894 & 3.849 & 5.554 \\
\hline \multirow[t]{4}{*}{ Total fat (kg) } & Mean & 9.315 & 6.306 & 6.787 & 5.781 & 9.040 \\
\hline & Std dev & 2.106 & 1.892 & 1.606 & 1.885 & 2.271 \\
\hline & Min & 4.854 & 2.633 & 4.585 & 2.114 & 4.483 \\
\hline & $\operatorname{Max}$ & 16.370 & 10.940 & 10.290 & 11.890 & 14.380 \\
\hline \multirow{4}{*}{$\begin{array}{l}\text { Carcass lean } \\
(\mathrm{kg})\end{array}$} & Mean & 13.283 & 10.713 & 12.222 & 10.249 & 12.775 \\
\hline & Std dev & 2.055 & 1.871 & 1.962 & 2.010 & 2.066 \\
\hline & Min & 8.539 & 5.542 & 7.668 & 5.959 & 8.179 \\
\hline & $\operatorname{Max}$ & 19.733 & 15.443 & 18.886 & 16.613 & 17.762 \\
\hline \multirow{4}{*}{$\begin{array}{l}\text { Non-fat } \\
\quad \text { visceral } \\
(\mathrm{kg})\end{array}$} & Mean & 5.669 & 5.616 & 5.140 & 5.450 & 5.163 \\
\hline & Std dev & 1.055 & 1.286 & 1.073 & 1.247 & 1.043 \\
\hline & Min & 3.404 & 2.890 & 3.604 & 2.936 & 2.933 \\
\hline & $\operatorname{Max}$ & 8.229 & 8.817 & 7.840 & 8.615 & 7.929 \\
\hline \multirow{4}{*}{$\begin{array}{l}\text { Empty body } \\
\text { weight }(\mathrm{kg})\end{array}$} & Mean & 30.590 & 25.081 & 26.344 & 23.751 & 29.156 \\
\hline & Std dev & 4.262 & 3.930 & 3.767 & 4.342 & 4.325 \\
\hline & Min & 18.662 & 13.333 & 17.884 & 13.862 & 18.921 \\
\hline & $\operatorname{Max}$ & 44.420 & 33.607 & 37.699 & 35.002 & 39.738 \\
\hline
\end{tabular}

Note. Std dev, standard deviation.

of $2739 \mathrm{cM}$. QTL analysis identified 9 QTLs for BD on a number of different chromosomes. The results in Table 3 are presented as weight- and age-adjusted QTLs. Four QTLs (those on chromosomes lp, lq, 4, and 7) were significant in either weight- or age-adjusted analysis, but not both (Table $3)$. However, in each case, a peak of lower significance is present in the other adjusted analysis (be it age or weight) and the allele substitution effects are similar. The most likely reason is that one adjustment has accounted for a larger proportion of the extraneous variance than the other, resulting in a lower residual standard error.

Of the nine QTLs which exceeded the suggestive criteria of Lander and Kruglyak [35], two were close to the signif- icance threshold. The permutation test of Churchill and Doerge [36] was used to determine appropriate genomewide significance thresholds for these two QTLs. A QTL for long BD identified on chromosome 1p (sire 608 weight adjusted, between markers BMS482, 92cM, and BM6438, $115 \mathrm{cM},-\log (\mathrm{p})=4.154)$, was significant $(P<0.05)$ (Fig. $5)$ according to this criterion. Another QTL for flat bone density on chromosome 24 (sire 608, weight and age adjusted, close to marker BP28, 28.8cM, $-\log (\mathrm{p})=3.988)$ was highly significant $(P<0.01)$ (Fig. 6).

Further statistical dissection of the QTLs for BD with the largest effects (QTLs on chromosomes 1p-long bones and 24-flat bones) showed that these QTLs contributed 9.6 and 


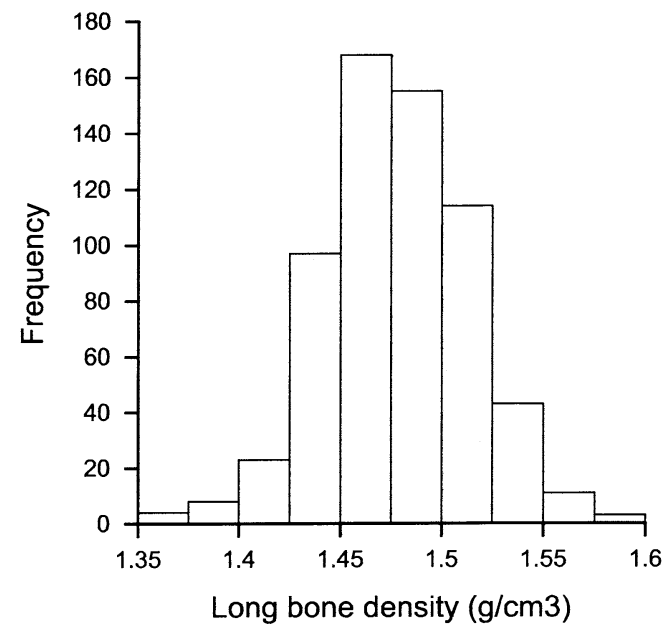

Fig. 1. Distribution of long bones of progeny (631 in total) from all sires. Mean $=1.478$, minimum $=1.355$, maximum $=1.585$, and standard deviation $=0.036$.

$9.7 \%$, respectively, of the phenotypic variation associated with BD traits in Coopworth sheep. The long bone and flat bone traits had heritabilities of 0.63 and 0.49 , respectively (Table 4). There were no differences in the significance of these QTLs in male or female progeny analysed separately.

QTL analysis of body composition traits was also carried out to establish whether there were any QTLs for other traits in the same region as BD QTLs. The highly significant BD QTL on chromosome 24 was coincided with minor QTLs for lean carcass content and nonvisceral components (identified using the 1 LOD drop off method) [37] (Fig. 6).

The power of the experiment to detect QTLs [38,39] at a genome-wide significance of 0.05 [35] was 0.65 and 0.88 when QTLs had effects of 0.5 and 0.7 phenotypic standard deviations per allelic substitution.

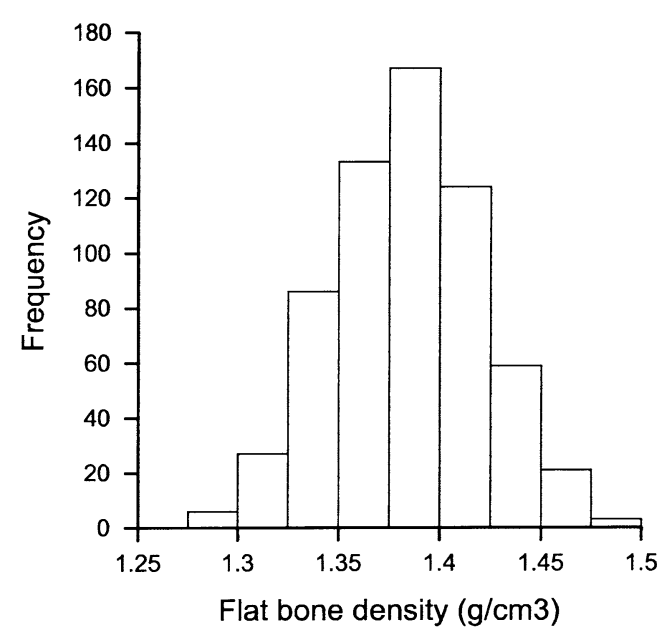

Fig. 2. Distribution of flat bones of progeny (631 in total) from all sires. Mean $=1.384$, minimum $=1.287$, maximum $=1.484$, and standard deviation $=0.036$.

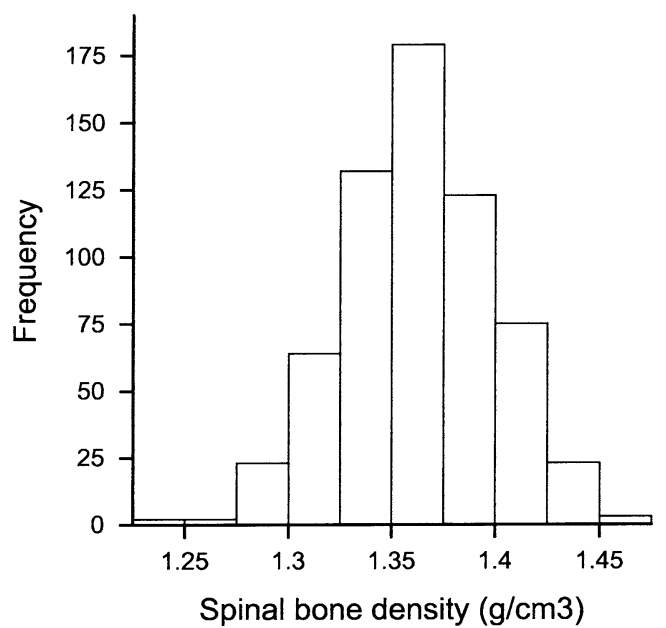

Fig. 3. Distribution of spinal bone density of progeny (631 in total) from all sires. Mean $=1.363$, minimum $=1.237$, maximum $=1.463$, and standard deviation $=0.036$.

\section{Discussion}

The aim of this study was to establish whether BD differed among sheep and, if so, whether the differences could be attributed to genetic components. We have shown that there were highly significant $(P<0.01)$ differences in $\mathrm{BD}$ among sires, demonstrating the importance of genetic components in contributing to BD variation in sheep. Sire 603 had consistently higher BD than other sire groups and sire 616 tended to have the lowest BD measurements (Table $1)$. Differences in BD were highly correlated $(P<0.01)$ with body weight and fat and muscle components. However, when the residuals were adjusted for body weight, BD was highly correlated $(P<0.01)$ with muscle components, but not consistently for fat components, with estimates close

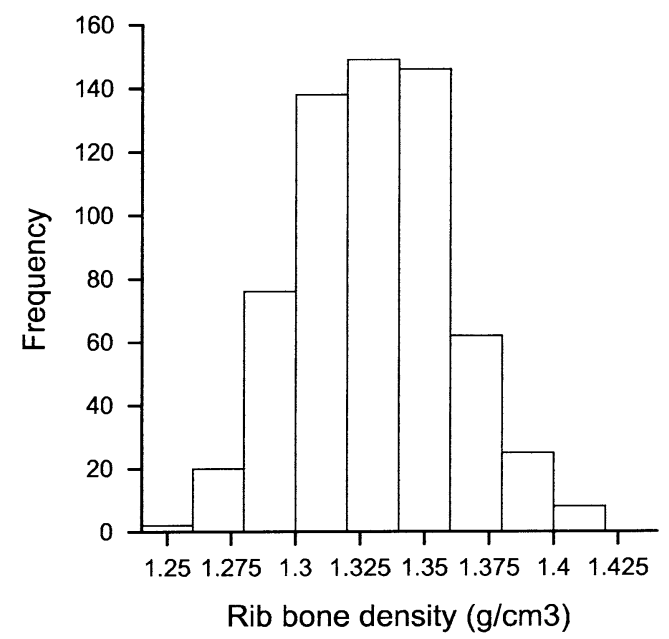

Fig. 4. Distribution of rib bone density of progeny (631 in total) from all sires. Mean $=1.331$, minimum $=1.245$, maximum $=1.412$, and standard deviation $=0.029$ 
Table 2

Correlations of residuals among bone density measurements and body composition measurements for progeny from all sires $(n=631)$

\begin{tabular}{|c|c|c|c|c|c|c|}
\hline & Subcutaneous fat & Intermuscular fat & Internal fat & Total fat & Carcass lean & Non-fat visera \\
\hline Long bones & 0.031 & 0.001 & $0.026^{*}$ & 0.027 & $0.136^{* *}$ & $-0.173 * *$ \\
\hline Flat bones & 0.022 & -0.063 & 0.097 & 0.034 & $0.119 * *$ & $-0.137 * *$ \\
\hline Spinal bones & $-0.09 *$ & $-0.09 *$ & -0.054 & $-0.095^{*}$ & $0.228 * *$ & $-0.197 * *$ \\
\hline Rib bones & $-0.15^{* *}$ & $-0.156^{* *}$ & -0.078 & $-0.156^{* *}$ & $0.179 * *$ & -0.025 \\
\hline
\end{tabular}

Note. Residuals were adjusted for birth rearing rank, sex, age, scan day, sire type, sire, and empty body weight. * and ** represent significance levels of $P<0.05$ and $P<0.01$, respectively.

to zero or slightly negative in the case of rib bones (Table 2 ), indicating that it is muscle that is important for BD rather than fat content in this study. Body weight and fat and muscle components are also correlated with BD in humans [40,41] and mice [42]. Sowers et al. [43] found that lean mass was associated with BD independent of fat mass, whereas fat mass was only associated with BD in the presence of high lean mass. In contrast, Reid et al. [44] showed associations between BD and fat mass, but not lean mass.

QTL analysis, within individual sires, revealed that there were nine QTLs for BD in this study which exceeded the suggestive criteria of Lander and Kruglyak [35] (Table 3). However, these criterion are conservative and two of the QTLs detected were very close to significance. These were a QTL for BD of long bones on chromosome 1p and a QTL for $\mathrm{BD}$ of flat bones on chromosome 24. For this reason the permutation test of Churchill and Doerge [36] was used to determine appropriate genome-wide significance thresholds for these traits. Using this criterion, both QTLs were shown to be significant (Figs. 5 and 6, respectively). Further dissection of these QTLs showed that they contributed 9-10\% of the phenotypic variation of BD of long bones and flat bones in sire 608. These traits had heritabilities of 0.63 and 0.49 , respectively (Table 4). From this we can estimate that the QTL on chromosome 1p contributes $15 \%$ of the genetic variation of long bones in sire 608 while the QTL on chromosome 24 contributes $20 \%$ of the genetic variation for flat bones in sire 608. A number of QTLs have been identified for BD in humans $[7,10,19,40]$, mice $[4,42,45,46]$, and baboons [17]. Comparative mapping using sheep, bovine, human, and mouse maps is a useful tool for identifying broad chromosomal regions that are homologous among species. Some of the QTLs identified in this study occur in the equivalent chromosome area as QTLs identified in human and mouse studies. For example, QTLs identified on human chromosomes $1 \mathrm{p}$ and $4 \mathrm{q}$ [27] are located in homologous positions to the sheep QTLs identified on chromosomes $1 \mathrm{p}$ and 17 , respectively. This may indicate the presence of common genes affecting BD in different species. The homologous sites in the human and mouse genomes to the sheep QTLs identified in this study are shown in Table 3.

A number of the QTLs identified in a mouse study

Table 3

Summary of QTLs identified for bone density in lean $\times$ fat backcross Coopworth sheep

\begin{tabular}{|c|c|c|c|c|c|c|c|c|c|c|c|}
\hline $\begin{array}{l}\text { Sheep } \\
\text { chromosome }\end{array}$ & $\begin{array}{l}\text { QTL region } \\
\text { interval }\end{array}$ & $\begin{array}{l}\text { Position } \\
(\mathrm{cM})\end{array}$ & Long & Flat & Spine & Ribs & $\begin{array}{l}\text { Weight } \\
\text { adjusted }\end{array}$ & $\begin{array}{l}\text { Age } \\
\text { adjusted }\end{array}$ & Sire & $\begin{array}{l}\text { Equivalent } \\
\text { human } \\
\text { chromosome }\end{array}$ & $\begin{array}{l}\text { Equivalent } \\
\text { mouse } \\
\text { chromosome }\end{array}$ \\
\hline $1 \mathrm{p}$ & BMS482-BM6438 & 103 & 4.154 & & & & $*$ & & 608 & $1 \mathrm{p} 32.3-\mathrm{q} 23.2$ & 3 or 4 \\
\hline $1 q$ & BM6438-MAF64 & 125 & & & 3.683 & & & $*$ & 616 & 21 & 10,16 , or 17 \\
\hline $1 q$ & BM648-MAF64 & 119 & & & 3.168 & & $*$ & & 616 & 21 & 10,16 , or 17 \\
\hline $1 q$ & BM648-MAF64 & 119 & & & & 2.805 & & $*$ & 616 & 21 & 10,16 , or 17 \\
\hline $2 q$ & BM6444-FCB11 & 298 & & & & 3.401 & & $*$ & 616 & $2 \mathrm{q} 21.1-\mathrm{q} 36.3$ & 1 or 2 \\
\hline 12 & TGLA53-BR6504 & 43 & & 2.793 & & & $*$ & & 610 & 1 & 1 \\
\hline 12 & TGLA53-BR6504 & 40 & & 2.858 & & & & $*$ & 610 & 1 & 1 \\
\hline 14 & Texan 10-MT2 & 21 & & & 3.214 & & $*$ & & 616 & 16 & 8 \\
\hline 14 & Texan 10-MT2 & 21 & & & 3.101 & & & $*$ & 616 & 16 & 8 \\
\hline 17 & BM8125-TGLA322 & 55 & & & 2.885 & & $*$ & & 616 & $4 / 12$ & $3 / 8$ \\
\hline 24 & BM4005-BP28 & 22 & 2.981 & & & & $*$ & & 608 & $16 \mathrm{p} 13.2-\mathrm{q} 11.2$ & $16 / 7$ \\
\hline 24 & BM4005-BP28 & 23 & 3.619 & & & & & $*$ & 608 & $16 \mathrm{p} 13.2-\mathrm{q} 11.2$ & $16 / 7$ \\
\hline 24 & $\begin{array}{l}\text { BP28-end of } \\
\text { chromosome }\end{array}$ & 28 & & 3.988 & & & $*$ & & 608 & $16 \mathrm{q} 13.2-\mathrm{q} 11.2$ & $16 / 7$ \\
\hline 24 & $\begin{array}{l}\text { BP28-end of } \\
\text { chromosome }\end{array}$ & 28 & & 3.986 & & & & $*$ & 608 & $16 \mathrm{p} 13.2-11.2$ & $16 / 7$ \\
\hline
\end{tabular}

Note. Nominal QTL significance measured as $-\log (\mathrm{p})$. Results presented are all those that exceed the suggestive threshold of Lander and Kruglyak [35] $(2.805-\log (\mathrm{p}))$. The results are presented as weight and age-adjusted analyses. 


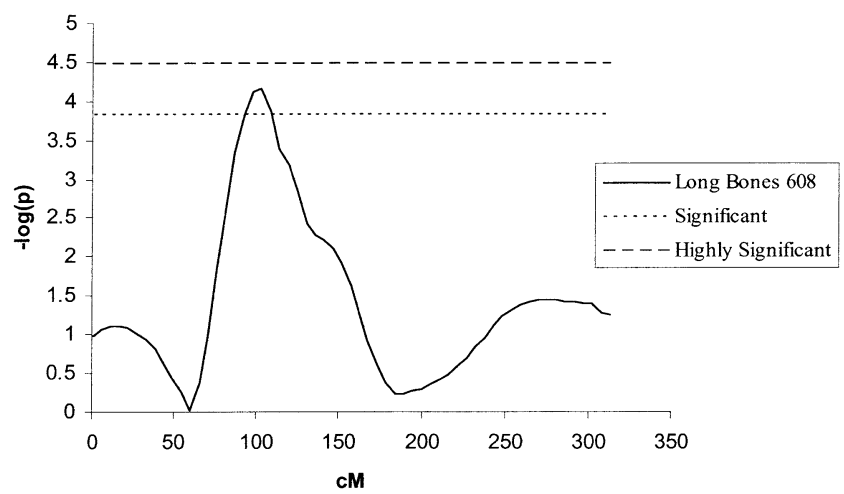

Fig. 5. QTL for bone density of long bones for sire 608 on sheep chromosome 1. Genome-wide significance determined using Churchill and Doerge criteria [36]. Markers are spaced as follows: BMS835 $=0$, OarCP93 $=28.6$, ILSTS29 $=53.9$, BMS482 $=91.9$, BM6438 $=114.9$, MAF64 $=131.6$, OarDB6 $=184.5$, MAF4 $=269$, BMS2263 $=303.4 \mathrm{cM}$

coincided with loci linked with adipose tissue and plasma high-density lipoprotein [42]. In the present study only one QTL (chromosome 24) coincided with QTL for other traits measured (Fig. 6). On chromosome 24, minor QTLs for non-fat visceral components (includes the visceral organs and contents of the small intestine and excludes the lungs and large intestine contents) and lean carcass components coincided with the BD QTL. In postslaughter data, not presented in this paper, QTLs for muscle components and hot carcass weight also coincided with the BD QTL on chromosome 24 . These results indicate that the identified region of chromosome 24 may be an area of importance for body composition studies. The locus/loci involved associated with the various traits could be closely linked or acting pleiotropically. Further fine mapping of this region would be required to determine this.

This is the first report of BD genetic variation and QTL detection for BD traits in sheep, although other studies have used sheep as a model for studying bone remodelling and osteoporosis [21,22,47-49]. The power to detect QTLs, based on the sizes of the $1 / 2 \mathrm{sib}$ families in this study, was shown to be high ( 0.65 and 0.88 given QTLs with effects of 0.5 and 0.7 phenotypic standard deviations, respectively). In addition to this, the genome scan in this study had an

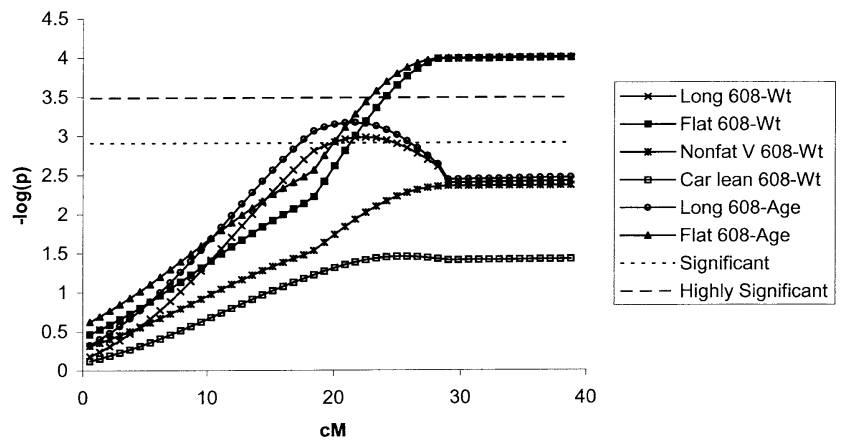

Fig. 6. QTLs for bone density and other morphological traits for sire 608 on sheep chromosome 24: QTLs were adjusted for age and weight (Wt). Genome-wide significance determined using Churchill and Doerge criteria [36]. Markers are spaced as follows: OarJMP29 $=0$, BM4005 $=18.3$, BP28 = $28.8 \mathrm{cM} \mathrm{NB}$. Long, long bones; flat, flat bones; nonfat V, non-fat visceral components, car lean, carcass lean components.

average distance between markers of $19.7 \mathrm{cM}$ which falls well within the criteria of $50 \mathrm{cM}$ required for detecting most QTLs [50]. Thus, we are confident that we have detected the majority of major QTLs segregating in this pedigree for BD, although we may have missed QTLs of small effect. The advantages of using sheep as a model for such studies are similar to those for any experimental animal model such as mice, in that environmental factors, such as diet, can be controlled. Similarly, large half- or full-sib families can be quickly generated (1 year) to investigate the genetic basis of a trait. Although sheep are larger than mice and more costly to maintain, their size is advantageous as a model for osteoporosis in that they have a similar body weight to humans, which is important given the associations between body weight and BD shown in humans and the associations in sheep seen in this study. Sheep have the added advantage that they have a similar bone remodelling process to humans [22].

The genetic variation shown in this study could be used for selection of low and high BD sheep lines for further study of BD genetics and isolation of genes involved. Lines bred for low BD would be ideal for studying the mechanisms responsible for bone fracture and healing and testing the effects of bone forming agents.

Table 4

Variation explained by presence of QTL for bone density (weight adjusted) on chromosomes $1 \mathrm{p}$ and 24 of Coopworth sheep

\begin{tabular}{lllllll}
\hline Trait & Chromosome & $\begin{array}{l}\text { Sire } \\
\text { segregating }\end{array}$ & $\begin{array}{l}\text { Allele substitution effect } \\
\text { (SD units) }(95 \% \mathrm{CI})\end{array}$ & $\begin{array}{l}\text { Percentage of } \\
\text { phenotypic } \\
\text { variance explained }\end{array}$ & $\begin{array}{l}\text { Length of } \\
\text { 1LOD support } \\
\text { interval (cM) }\end{array}$ & $\begin{array}{l}\text { Heritability } \\
\text { of BD for } \\
\text { the trait }\end{array}$ \\
\hline Long & 1 & 608 & $0.75(0.39,1.13)$ & 9.6 & 33 & $0.63 \pm 0.14$ \\
Flat & 24 & 608 & $0.64(0.33,0.94)$ & 9.7 & N/A & $0.49 \pm 0.14$ \\
\hline
\end{tabular}

Note. N/A indicates that QTL is at the end of the chromosome. 


\section{Acknowledgments}

The authors thank Professor Ailsa Goulding for her review of the manuscript. This work was in part funded by the FRST New Zealand Public Good Science Fund. CT scanning was provided by InnerVision and Landcorp Farming Ltd.

\section{References}

[1] Cummings SR, Black DM, Nevitt MC. Appendicular bone density and age predict hip fracture in women. JAMA 1990;263:665-8.

[2] Deng H-W, Chen W-M, Recker S, Stegman MR, Li J-L, Davies KM, Zhou Y, Deng H, Heaney R, Recker RR. Genetic determination of Colles' fracture and differential bone mass in women with and without Colles' fracture. J Bone Miner Res 2000;15:1243-52.

[3] Hui SL, Slemenda CW, Johnstone CC. Age and bone mass as predictors of fracture in a prospective study. J Clin Inves 1988;81: 1804-6.

[4] Beamer WG, Shultz KL, Churchill GA, Frankel WN, Baylink DJ, Rosen CJ, Donahue LR. Quantitative trait loci for bone density in C57BL/6J and CAST/EiJ inbred mice. Mamm Genome 1999;10: 1043-49.

[5] Slemenda CW, Christian JC, Williams CJ, Norton JA, Johnstone CC. Genetic determinants of bone mass in adult women: a reevaluation of the twin model and the potantial importance of gene interaction on heretibility estimates. J Bone Miner Res 1991;6:561-7.

[6] Young D, Hopper JL, Nowson CA, Green RM, Sherwin AJBK, Smid M, Guest GS, Larkins RG, Wark JD. Determinants of bone mass in 10-26 year old females: a twin study. J Bone Miner Res 1995;10: $558-67$.

[7] Cohen-Solal ME, Baudin C, Omouri M, Kuntz D, De Vernejoul MC. Bone mass in middle-aged osteoporotic men and their relatives: familial effect. J Bone Miner Res 1998;13:1909-14.

[8] Danielson ME, Cauley JA, Baker CE, Newman AB, Dorman JS, Towers JD, Kuller LH. Familial resemblance of bone mineral density (BMD) and calcaneal ultrasound attenuation: the BMD in mothers and daughters study. J Bone Miner Res 1999;14:1909-14.

[9] McKay HA, Bailey DA, Wilkinson AA, Houston CS. Familial comparison of bone mineral density at the proximal femur and lumbar spine. Bone Miner 1994;24:95-107.

[10] Koller DL, Rodriguez LA, Christian JC, Slemenda CW, Econs MJ, Hui SL, Morin P, Conneally PM, Joslyn G, Curran ME, Peacock M, Johnston CC, Foroud T. Linkage of a QTL contributing to a normal variation in bone mineral density to chromosome 11q12-13*. J Bone Miner Res 1998;13:1903-8.

[11] Houston LA, Grant SFA, Reid DM, Ralston SH. Vitamin D receptor polymorphism, bone mineral density and osteoporotic vertebral fracture: studies in a UK population. Bone 1996;18:249-52.

[12] Spector TD, Keen RW, Arden NK. Influence of vitamin D receptor genotype on bone mineral density in post-menopausal women: a twin study in Britain. B Med J 1995;310:1357-60.

[13] Hustmyer FG, Peacock M, Hui S, Johnstone CC, Christian J. Influence of vitamin D receptor gene locus. Journal of Clinical Investigation 1994;94:2130-4.

[14] Looney JE, Yoon HK, Fischer M, Farley SM, Farley JR, Wergedal JE, Baylink DJ. Lack of high prevalence of the BB vitamin D receptor genotype in severely osteoporotic women. J Clin Endocrinol Metab 1995;80:2158-62.

[15] Devoto M, Shimoya K, Caminis J, Ott J, Tenenhouse A, Whyte MP, Sereda L, Hall S, Considine E, Williams CJ, Tromp G, Kuivaniemi H, Ala-Kokko L, Prockop DJ, Spotila LD. First-stage autosomal genome screen in extended pedigrees suggests genes predisposing to low bone mineral density on chromosomes $1 \mathrm{p}, 2 \mathrm{p}$ and $4 \mathrm{q}$. Eur $\mathrm{J}$ Hum Gene 1998;6:151-7.

[16] Devoto M, Specchia C, Li HH, Caminis J, Tenenhouse A, Rodriguez $\mathrm{H}$, Spotila LD. Variance component linkage analysis indicates a QTL for femoral neck bone mineral density on chromosome 1p36. Hum Mol Genet 2001;10:2447-52.

[17] Mahaney MC, Morin P, Rodriguez LA, Newman DF, Rodgers J. A quantitative trait locus on chromosome 11 may influence bone mineral density at several sites: linkage analysis in pedigreed baboons. J Bone Miner Res 1997;12:S37-S118.

[18] Little RD, Cuarulli JP, Del Mastro RG, Dupuis J, Osborne M, Folz C, Manning SP, Swain PM, Zhao S-C, Eustace B, Lappe MM, Spitzer L, Zweier S, Braunschweiger K, Benchekroun Y, Hu X, Adair R, Chee L, FitzGerald MG, Tulig C, Caruso A, Tzellas N, Bawa A, Franklin B, McGuire S, Nogues X, Gong G, Allen KM, Anisowicz A, Morales AJ, Lomedico PT, Recker SM, Van Eerdewegh P, Recker RR, Johnson ML. A mutation in the LDL receptor-related protein 5 gene results in the autosomal dominant high-bone-mass trait. Am J Hum Genet 2002;70:11-9.

[19] Johnson ML, Gong G, Kimberling W, Recker SM, Kimmel DB, Recker RR. Linkage of a gene causing high bone mass to human chromosome 11 (11q12-13). Am J Hum Genet 1997;60:1326-32.

[20] Newman E, Turner AS, Wark JD. The potential of sheep for the study of osteopenia: current status and comparison with other animals. Bone 1995;16:277S-84S.

[21] Chavassieux P, Buffer A, Vergnaud P, Garnero P, Meunier PJ. Shortterm effects of corticosteroids on trabecular bone remodeling in old ewes. Bone 1997;20:451-5.

[22] Lill CA, Fluegal AK, Schneider E. Sheep model for fracture treatment in osteoporotic bone: a pilot study about different induction regimes. J Orthop Trauma 2000;15:559-65.

[23] Turner AS, Mallinckrodt CH, Alvis MR, Bryant HU. Dose-response effects of estradiol implants on bone mineral density in ovariectomized ewes. Bone 1995;17:421S-7S.

[24] Morris CA, McEwan JC, Fennessey PF, Bain WE, Greer GJ, Hickey SM. Selection for high or low backfat depth in Coopworth sheep: juvenile traits. Anim Sci 1997;65:93-103.

[25] Jopson NB, McEwan JC, Young MJ, Stuart SK, Veenvliet BA, Littlejohn RP, Suttie JM. Body composition and growth hormone profiles in first-cross progeny of genetically lean and fat sheep. Proceedings of the 6th World Congress on Genetics Applied to Livestock Production, Armidale, Australia, January 11-16, 1998. Volume 24: Sheep and Goats (Meat and Milk); Poultry; Horses; Buffalos. 1998;24:157-60.

[26] Jopson NB, Thompson JM, Fennessey PF. Tissue mobilization rates in male fallow deer (Dama dama) as determined by computed tomography: the effects of natural and enforced food restriction. Anim Sci 1997;65:311-20.

[27] Gundersen HJG, Bendtsen TF, Korbo L, Marcussen N, Moller A, Nielsen K, Nyengaard JR, Pakkenberg B, Sorensen FB, Vesterby A, West MJ. Some new, simple and efficient stereological methods and their use in pathological research and diagnosis. Acta Pathol Microbiol Immul Scand 1988;96:379-94.

[28] Fullerton GD. Fundamentals of CT tissue characterisation. In: Fullerton GD, Zagzebski JA, editors. Medical physics of ultrasound tissue imaging and characterization, medical physics monograph, No. 6. American Institute of Physics; 1980, p. 125-62.

[29] Laval-Jeantet AM, Roger B, Bouysse S, Bergot C, Mazess RB. Influence of vertebral fat content on quantitative CT density. Radiology 1986;159.

[30] Montgomery GW, Sise JA. Extraction of DNA from sheep white blood cells. N Z J Agr Res 1990;33:437-41.

[31] Maddox JF, Davies KP, Crawford AM, Hulme DJ, Vaiman D, Cribu EP, Freking BA, Beh KJ, Cockett NE, Kang N, Riffkin CD, Drinkwater R, Moore SS, Dodds KG, Lumsden JM, van Stijn TC, Phua SH, Adelson DL, Burkin HB, Broom JE, Buitkamp J, Cambridge L, Cushwa WT, Gerard E, Galloway SM, Harrison B, Hawken RJ, 
Hiendleder S, Henry HM, Medrano JF, Paterson KA, Schibler L, Stone RT, van Hest B. An enhanced linkage map of the sheep genome comprising more than 1000 loci. Genome Res 2001;11:1275-89.

[32] Knott SA, Elsen J-M, Haley CS. Methods for multiple-marker mapping of quantitative trait loci in half-sib populations. Theoret Appl Genet 1996;93:71-80.

[33] Johnstone, P.D., Baird, D.B. An implementation of Haley Knott least squares method for mapping quantitative trait loci in half sib populations. 5th Australasian Genstat Conference, pp. 23. Mecure Resort, Surfers Paradise, Queensland, Australia; 2001.

[34] Aitken M. The analysis of unbalanced cross-classifications. J R Statist Soc A 1978;141:195-223.

[35] Lander E, Kruglyak L. Genetic dissection of complex traits: guidelines for interpreting and reporting linkage results. Nat Genet 1995; 11:241-7.

[36] Churchill GA, Doerge RW. Emperical threshold values for quantitative trait mapping. Genetics 1994;138:963-71.

[37] Lander ES, Botstein DB. Mapping Mendilian factors underlying quantitative traits using RFLP linkage maps. Genetics 1989;1212: $185-99$.

[38] Slate J, Pemberton JM, Visscher PM. Power to detect QTL in a free-living polygynous population. Heredity 1999;83:327-36.

[39] Weller JI, Kashi Y, Soller M. Power of daughter and grandaughter designs for determining linkage between marker loci and quantitative trait loci in dairy cattle. J Dairy Sci 1990;73:2525-37.

[40] Hobson EE, Ralston SH. Role of genetic factors in the pathophysiology and management of osteoporosis. Clin Endocrinol 2001;54:1-9.

[41] Seeman E, Hopper JL, Young NR, Formica C, Goss P, Tsalamandris C. Do genetic factors explain associations between muscle strength, lean mass, and bone density? A twin study. Am J Physiol 1996;270:E320-7.

[42] Drake TA, Schadt E, Hannani K, Kabo JM, Krass K, Colinayo V, Greaser LE, Goldin J, Lusis AJ. Genetic loci determining bone density in mice with diet-induced athersclerosis. Physiol Genom 2001;5:205-15.

[43] Sowers MR, Kshirsagar A, Crutchfield MM, Updike S. Joint influence of fat and lean body composition compartments on femoral bone mineral density in young women. Am J Epidemiol 1992;136:257-65.

[44] Reid IR, Ames R, Evans MC, Sharpe S, Gamble JT, France TM, Lim T, Cundy TF. Determinants of total body and regional bone mineral density in normal postmenopausal women-a key role for fat mass. J Clin Endocrinol Metab 1992;75:45-51.

[45] Klein RF, Mitchell SR, Phillips TJ, Belknap JK, Orwoll ES. Quantitative trait loci affecting peak bone mineral density in mice. J Bone Miner Res 1998;13:1648-56.

[46] Shimizu M, Higuchi K, Bennett B, Xia C, Tsuboyama T, Kasai S, Chiba T, Fujisawa H, Kogishi K, Kitado H, Kimoto M, Takeda N, Matsushita M, Okumura H, Serikawa T, Nakamura T, Johnson TE, Hosokawa M. Identification of peak bone mass QTL in a spontaneously osteoporitic mouse strain. Mamm Genome 1999;10:81-7.

[47] Chavassieux P, Pastoureau P, Boivin G, Chapuy MC, Delmas PD, Meunier PJ. Dose effects on ewe bone remodeling of short-term sodium fluoride administration-a histomorphometric and biochemical study. Bone 1991;12:421-7.

[48] Pastoureau P, Meunier PJ, Delmas PD. Serum osteocalcin (bone gla-protein), an index of bone growth in lambs. Comparison with age-related histomorphometric changes. Bone 1991;12:143-9.

[49] Rubin C, Turner AS, Muller R, Mittra E, McLeod K, Lin W, Qin $\mathrm{Y}-\mathrm{X}$. Quantity and quality of trabelcular bone in the femur are enhanced by a strongly anabolic, noninvasive mechanical intervention. J Bone Miner Res 2002;17:349-57.

[50] Darvasi A, Soller M. Optimum spacing of genetic markers for determining linkage between marker loci and quantitative trait loci. Theoret Appl Genet 1994;89:351-7. 